Title

\title{
Effects of accession, spacing and pruning management on in-situ leaf litter decomposition of Jatropha curcas L. in Zambia
}

\author{
Aklilu Negussie ${ }^{1,2^{*}}$, Jeroen Degerickx ${ }^{1}$, Lindsey Norgrove ${ }^{3 *}$, Wouter M.J. Achten ${ }^{4}$, Kiros \\ Meles Hadgu ${ }^{2}$, Ermias Aynekulu$^{5}$, Bart Muys $^{1}$ \\ ${ }^{1}$ Division Forest, Nature and Landscape, University of Leuven, Celestijnenlaan 200E-2411, Leuven, Belgium \\ ${ }^{2}$ World Agroforestry Centre (ICRAF), P. O. Box 5689, Addis Ababa, Ethiopia \\ ${ }^{3}$ Department of Environmental Sciences (Biogeography), University of Basel, St Johanns Vorstadt 10, CH-4056 \\ Basel, Switzerland \\ ${ }^{4}$ Institute for Environmental Management and Land Use Planning (IGEAT), Université Libre de Bruxelles \\ (ULB), Avenue F.D. Roosevelt, 50 CP 130/02, 1050 Brussels, Belgium \\ ${ }^{5}$ World Agroforestry Centre (ICRAF), United Nations Avenue, P. O. Box 30677-00100, Nairobi, Kenya \\ "Corresponding authors
}

\section{Authors' e-mail addresses}

aklilumekuria@gmail.com; Jeroen.Degerickx@ees.kuleuven.be; lindsey.norgrove@unibas.ch and Norgrove@airpost.net; wouter.achten@ulb.ac.be; K.Hadgu@cgiar.org; e.betemariam@cgiar.org;

Bart.Muys@ees.kuleuven.be

\section{*Corresponding authors}

Dr. Aklilu Negussie: World Agroforestry Center (ICRAF), P.O. Box 5689, Addis Ababa, Ethiopia; Tel: + 251 920743719; e-mail: aklilumekuria@gmail.com

Dr. Lindsey Norgrove: Department of Environmental Sciences (Biogeography), University of Basel, St Johanns Vorstadt 10, CH-4056 Basel, Switzerland; e-mail: lindsey.norgrove@unibas.ch and Norgrove@airpost.net

\section{Paper type}

Original Research 


\begin{abstract}
Jatropha curcas L. leaf litter decomposition and subsequent nutrient release was monitored in three experimental $J$. curcas plantations in Zambia, comparing accessions from six countries, pruned versus non-pruned and different plant spacings. Leaf litter production was low (267-536 kg ha ${ }^{-1}$ at the end of the growing season) and contained, on average, $1.23 \% \mathrm{~N}$, $0.14 \% \mathrm{P}$ and $2.61 \% \mathrm{~K}$. Litter decomposed rapidly, losing $80 \%$ of total mass by 70 to 105 days after incubation in the field and followed a negative exponential pattern with an average decomposition constant, $\mathrm{k}$, of 0.08 week $^{-1}$. No significant effects of plant accession, plant spacing or pruning on the decomposition rate were detected. $\mathrm{K}, \mathrm{P}, \mathrm{Mg}$ and $\mathrm{Na}$ had nutrient release rates exceeding mass loss, explained by their high mobility and solubility, together with high soil temperature and rainfall conditions. Others, such as $\mathrm{Ca}$ and $\mathrm{Mn}$, were initially retained in the decaying leaf litter before later release. The rate of $\mathrm{N}$ release closely approached that of mass loss. Jatropha curcas litter can be a supplemental source of nutrients in areas known for nutrient deficiency and low organic matter, which represents an additional input in intercropping systems above biofuel production. Considering that the total primary nutrient input through $J$. curcas litterfall to the soil is limited (for example, for nitrogen between 9.7 and $14.2 \mathrm{~g} \mathrm{~kg}^{-1}$ and for phosphorus between 0.8 and $1.9 \mathrm{~g} \mathrm{~kg}^{-1}$ ), organic or mineral fertilizer application remains crucial to satisfy fully the nutrient requirements of surrounding crops.
\end{abstract}

Key words: Africa; agroforestry; biofuel, litter bag experiment; nutrient cycling

\title{
1. Introduction
}

Jatropha curcas L. (family Euphorbiaceae) is a small tropical tree with a lifespan of about 50 years [1]. Due to its popularity as a feedstock for biodiesel production, its medicinal values [2] and its potential to rehabilitate and grow in dry degraded lands, there is increasing interest to intensify J. curcas cultivation in tropical and subtropical regions [3-6]. The species can be cultivated as a monoculture or intercropped with annual and perennial crops [7,8]. However, monocultural $J$. curcas systems have recently raised controversies, as they may increase food insecurity risk in areas where land shortage is prevalent [9]. In this case, the previously mentioned concerns are circumvented and some other additional benefits can be gained from 
the $J$. curcas trees, like the addition of nutrients to the soil through litterfall. As the majority of soils in Africa are characterized by deficiencies of N, P, K, low soil organic matter [10-12] and the world's lowest mineral fertilizer application rates [11], this additional service could significantly improve soil fertility and hence crop an fodder yields. J. curcas has been shown to increase soil $\mathrm{pH}$ and maintain higher soil microbial biomass and activity [13]. In Senegal, under low rainfall conditions (400 - $600 \mathrm{~mm} \mathrm{year}^{-1}$ ), Dieng et al. [14] assessed topsoil under one-year old J. curcas plantations and found significantly higher total soil C, N and P than under adjacent paired fallow sites representing the previous land use system. A study from Burkina Faso also demonstrated that J. curcas associated with cereal crops is more profitable than monocropping cereals [13]. Although more experience and studies are needed on how to intercrop J. curcas with food crops on arable lands, integration into the local food production system as hedges and small woodlots might play a significant and less contentious role in sustainable food and energy production systems for smallholder farmers [9] and thus may directly benefit the rural economy [7].

Yet there is little information available on the production, quality and nutrient release dynamics of $J$. curcas leaf litter, even though such characteristics would partially determine its potential to rehabilitate land and to be integrated in intercropping systems. Litter quality refers to the characteristics of the litter (chemistry and physical attributes) that influence its susceptibility to decomposition [15]. This is species-dependent although such traits exhibit phenotypic plasticity according to the growing conditions and accessions $[5,16]$. Some studies (e.g., [17,18]) highlight the requirement for a detailed investigation of litter production, quality and nutrient release of different plant species to develop reliable information on their functions and management.

Different $J$. curcas accessions have been introduced to Africa long ago, which are a subset of the Central American genetic diversity [19-21]. Plants, of different accessions managed in different ways, can have different decomposition trends [22]. So far, only one study was found which assessed the impact of management factors on the decomposition rate of $J$. curcas litter in Ghana [7]. They concluded that J. curcas leaf litter has potential as a source of nutrients and highlighted the significant impact of canopy closure on the litter decomposition rate through its direct effect on soil temperature. The impact of plant accession on the decomposition of $J$. curcas litter remains however unknown. 
Rulli et al. [26] recently compiled a list of large-scale J. curcas projects, each exceeding 200 hectares, in Zambia and three of its neighbouring countries, Democratic Republic of Congo, Tanzania and Mozambique. They calculated that the total area exceeded 50,000 $\mathrm{Km}^{2}$, implying that the potential impact of $J$. curcas is huge. Considering such expansion in Africa, it is essential to understand its nutrient dynamics and impact in representative environments. In situ litter decomposition experiments of different accessions under different management regimes provide preliminary data on assessing nutrient dynamics. This would help to generate useful knowledge on methods of how to grow J. curcas with food crops to secure both energy and food production systems in the region with minimal external agricultural inputs. In addition, estimating litter inputs and decomposition may provide more insight into carbon fluxes and nutrient cycling [27]. The changes in litter turnover through decomposition may also help to understand vegetation-soil feedbacks, improving forecasts of the global carbon stock, climate warming and other global environmental changes, which is the current research priority of many countries.

In this study, we estimated the potential of $J$. curcas leaf litter as an additional source of nutrients to the soil and assess the effects of both plant accession and management (pruning regime and spacing) on this service, in three J. curcas trials. In particular, this study aimed to: (i) estimate the total nutrient input to the soil through J. curcas litterfall, (ii) determine leaf litter decay rates of different accessions of $J$. curcas under different management practices and (iii) assess the nutrient release trend and fibre content changes in the decomposing leaf litter of $J$. curcas over time.

\section{Materials and methods}

\subsection{Study site and plant material}

The study was conducted from April 2010 until July 2011 in three J. curcas plantation trials in Zambia, Southern Africa. All trials were located in Chongwe district, $24 \mathrm{~km}$ Northeast of central Lusaka $\left(15^{\circ} 22^{\prime} 09^{\prime}\right.$ S; $28^{\circ} 27^{\prime} 33^{\prime}$ E) at an elevation of $1160 \mathrm{~m}$ a.s.1. The mean annual maximum and minimum temperatures are 26 and $14{ }^{\circ} \mathrm{C}$, respectively. The area is characterized by a long rainy season between late October and May and a mean annual rainfall of $802 \mathrm{~mm}$. During the experimental period (between October 2010 and July 2011) 
the monthly rainfall ranged from 35 to $244 \mathrm{~mm}$ with a total rainfall of $869 \mathrm{~mm}$ (Figure 1). The maximum and minimum temperatures within this period are given in Figure 1.

The first trial, i.e. the accession trial, comprised six accessions collected from three continents, Asia (India and Thailand), South America (Mexico) and Africa (Zambia, Mali, and Cape Verde). The accessions were planted in six unreplicated plots of $13.5 \times 5 \mathrm{~m}$, each containing 18 trees from the same accession, at $1.5 \times 2.5 \mathrm{~m}$ spacing $\left(2667 \mathrm{ha}^{-1}\right)$. Seeds from foreign accessions were imported from their respective country of origin and directly used in the trial (i.e. first generation in Zambia). All trees were established from seed with seedlings raised in a nursery, close to the plantation site. The second trial was a pruning trial with a one-factorial design at two levels, each replicated four times. Plots contained nine trees that were either pruned before the beginning of the rainy season (October) or left unpruned. Plot sizes were $9 \times 6 \mathrm{~m}$ and trees (Cape Verdean accession) were established from seed and spaced at $2 \times 3 \mathrm{~m}\left(1667 \mathrm{ha}^{-1}\right)$. The third trial was a spacing trial with a one-factorial design at three levels, i.e. plant spacing of $4 \times 4 \mathrm{~m}\left(625 \mathrm{ha}^{-1}\right), 2 \times 3 \mathrm{~m}\left(1667 \mathrm{ha}^{-1}\right)$ and $2 \times 2 \mathrm{~m}(2500$ $\left.\mathrm{ha}^{-1}\right)$. Each treatment was applied in four plots, each containing nine trees of Cape Verdean accession and established from seed. All trials were rainfed and were planted at the end of 2008. In the first year, trials were fertilized with $42 \mathrm{~g} \mathrm{~N}, 12 \mathrm{~g} \mathrm{P}$, and $48 \mathrm{~g}$ elemental $\mathrm{K}$ per tree in the form of urea, single superphosphate and potassium chloride, respectively. The nutrients were applied twice per year (mid-February and early April). Trees from the accession and spacing trials were pruned at the first year of establishment in September 2008. The site has well-drained, moderately shallow sandy-clay-loam soils with an average depth of $1 \mathrm{~m}$, classified as Ferric Luvisols based on the FAO classification system [28]. The soils of all trials were slightly acidic and were low in available phosphorus and soil organic matter. The physical and chemical soil properties at the different trials are displayed in Table 1.

(Insert figure 1)

(Insert table 1) 


\subsection{Litter production}

To estimate litter production per tree, 11 leaf litter traps (one for each treatment) were stretched around one tree per treatment, selected randomly, between April and July 2010. Litter traps consisted of mosquito netting ( $2 \mathrm{~mm}$ mesh) placed $50 \mathrm{~cm}$ above the soil surface, with a surface area of $6.25 \mathrm{~m}^{2}$ aimed to cover the entire canopy. Litter was harvested from the traps every week and oven dried to estimate total dry matter weight.

\subsection{Litter collection and initial quality assessment}

Jatropha curcas litter was collected during the peak leaf fall period at the beginning of the dry season from May to July 2010. An additional nine litter traps were placed randomly in each trial during this period in a similar fashion as the first 11 traps. The traps were mounted between 4 trees and switch to other trees every 10 days within the same treatment. The surface areas of the traps were $6 \mathrm{~m}^{2}$ and $16 \mathrm{~m}^{2}$ respectively for pruning and spacing trials and $3.7 \mathrm{~m}^{2}$ for the accession trial with smaller plant spacing. Litter was collected every ten days and air dried. Composite sub-samples of litter were collected for each treatment separately and oven dried at $65^{\circ} \mathrm{C}$ for 72 hours. After oven drying, the samples were milled to analyse for macro- and micro-nutrients and fibre content. For the decomposition experiment, all airdried litter samples were bulked together per treatment and homogenized before bagging.

\subsection{Litter bag incubation, decomposition and nutrient analysis}

The most frequently used method to determine litter decomposition rates is the litterbag technique [27,29]. In this method, a known amount of newly shed litter is enclosed in bags with appropriate mesh sizes and laid on the soil surface or buried in the soil to collect and measure the remaining mass in periodic intervals. In our case, in situ litter decomposition of six J. curcas accessions (Mexican, Indian, Thai, Zambian, Malian, and Cape Verdean) and litter harvested from trees with different canopy management (pruning and plant spacing) was determined over nine months (between October 2010 and June 2011). Four grams (4 g) of air dried $J$. curcas litter, weighed using a precision balance $( \pm 0.001 \mathrm{~g})$, was carefully put into $0.20 \times 0.20 \mathrm{~m}$ nylon litter decomposition bags with a $1 \mathrm{~mm}$ mesh size. The litter was not 
shredded before placing in the bags to maintain its natural form in field conditions. This mesh size avoids excessive particle loss in in situ experimental conditions, while allowing free access for all soil micro-fauna and most meso-fauna [30]. One hundred and ninety eight (198) litter bags were prepared (11 treatments $\times 3$ replications $\times 6$ recovery dates $)$ and placed randomly under J. curcas trees of the respective treatments. The bags were placed on the soil surface and covered with surrounding leaf litter to mimic field conditions. All bags were numbered using trial and tree number and fixed to the soil surface with metal pegs. One bag was removed from each plot at 2, 4, 8, 14, 24, and 34 weeks after placement. After retrieval, each sample was put in a paper envelope. Adhering soil, soil fauna and other extraneous materials were carefully removed from the bag by brushing or swiftly rinsing with water. The remaining litter sample was oven dried for $72 \mathrm{~h}$ at $65^{\circ} \mathrm{C}$ and weighed using a precision balance $( \pm 0.001 \mathrm{~g})$. The three replications per treatment were bulked for nutrient analysis since the amount of remaining litter per bag was often too small to be analysed separately. C and $\mathrm{N}$ concentrations were determined using a CN analyser (Carlo Erba 1110 Elemental Analyser) and a ratio of carbon to nitrogen $(\mathrm{C}: \mathrm{N})$ on a weight basis was then derived based on the result. Concentrations of $\mathrm{P}, \mathrm{K}, \mathrm{Mg}, \mathrm{Mn}, \mathrm{Na}$, and $\mathrm{Ca}$ were analysed using inductively coupled plasma emission spectroscopy (ICP) with EPA method after $\mathrm{HNO}_{3}$ digestion. Crude fibre content (lignin, cellulose and hemi-cellulose) was analysed using the fractionation method Van Soest [31] and Van Soest et al. [32]. To analyse these different crude fibre constituents, dried litter samples were digested in a detergent solution, which separated nonpolar extractives (NPE) from neutral detergent fibre (NDF), which includes fractions that are not immediately nutritionally available. A dilute acid detergent solution was then used to determine acid detergent fibre (ADF, lignocellulose) before lignin was separated from cellulose in $72 \% \mathrm{H}_{2} \mathrm{SO}_{4}$.

\subsection{Data analysis}

Litter production was expressed in $\mathrm{kg} \mathrm{ha}^{-1}$ by multiplying the amount of leaves trapped per tree to the total number of trees per ha. Before analysing the data obtained from the decomposition experiment, the remaining dry weight of litter and the remaining nutrient content ( $=$ mass of remaining litter $\times$ nutrient concentration) at each time step were expressed as a fraction of the initial litter weight and initial nutrient content respectively. The mass decomposition and nutrient release data were analysed after Wieder \& Lang [33]: differences 
between treatments were analysed using two-way ANOVA with time, treatment and the interaction term included in the model, combined with a Tukey post-hoc test. Both the assumption of normality and homogeneity of variance were verified using the Shapiro-Wilk and Levene's test, respectively. In case the assumption of homogeneity of variance was violated by the data, a significance level of $\alpha=0.01$ rather than 0.05 was used to prevent the occurrence of Type I errors. A single negative exponential function was used to further describe the data and estimate a decomposition rate constant $(\mathrm{k})$ for each treatment [34]. This function is well-supported by decomposition theory [33].

$$
\mathrm{X}_{\mathrm{t}}=\mathrm{X}_{0} \times \exp ^{-\mathrm{kt}}
$$

where $X_{t}$ is the remaining litter weight or nutrient content at time $t, X_{0}$ is the initial litter weight or nutrient content, $\mathrm{k}$ is the decomposition rate constant, and $\mathrm{t}$ is the time in weeks. These $\mathrm{k}$ values were then related to the initial nutrient content of the litter, which is known to have a primary effect on litter decomposition (e.g. [35]), by calculating the Pearson correlation coefficients. All data were analysed using SPSS 17.0 software (IBM, Chicago, USA).

\section{Results}

\subsection{Litter production}

The average litter deposition per treatment during the dry season between May and July varied between $111 \mathrm{~kg} \mathrm{ha}^{-1}$ and $581 \mathrm{~kg} \mathrm{ha}^{-1}$ for the different experiments (Table 2). Litter production is primarily affected by plant spacing.

(Insert table 2)

\subsection{Initial leaf litter chemical constituents}

J. curcas leaf litter chemistry is in Table 3. The Mexican accession had the highest $\mathrm{P}$ concentration (up to $61 \%$ higher compared to the lowest value in the Indian accession). The 
$\mathrm{C}: \mathrm{N}$ ratio of the six accessions ranged between 31 and 36 with the highest value for the Indian accession, however there was no consistent effect of accession on $J$. curcas litter nutrient concentrations. Similarly, the lignin concentration of the Indian accession was higher (up to $127 \%$ ) compared to the lowest value of the Zambian accession. A higher C:N ratio was observed for the accession and spacing trials compared to the pruning trial, however this can be attributed to the differences in soil fertility between the different fields (Table 1).

(Insert table 3)

\subsection{Total leaf litter nutrient content}

Annual leaf litter nutrients added to the soil were calculated based on litter production and its nutrient content and are displayed in Table 4. Plant spacing affected the total amount of nutrients that can be added to the soil through litterfall during this early plantation stage. Other treatments had no significant effect.

(Insert table 4)

\subsection{Litter mass decomposition}

The decomposition pattern of $J$. curcas leaves is similar between treatments (Figure 2). A low rate of mass loss during the first four weeks of incubation is followed by an exponential decomposition trend. The rate of mass loss is reduced after 10 to 15 weeks when approximately $80 \%$ of the initial mass has decomposed. The period of maximal rate of decomposition coincided with the rainfall peak period of December and January and higher soil temperature and soil moisture (Figure 1). All material was decomposed 34 weeks after incubation.

The analyses of variance conducted for each trial was revealed no significant effects of plant accession $(P=0.118)$, plant spacing $(P=0.636)$ or pruning $(P=0.703)$ on the decomposition rate of $J$. curcas leaves. The interaction term treatment $\times$ time was not significant $(P=$ 
0.057), meaning that any treatment effect was independent of time. These results are confirmed by the small and non-significant differences in estimated k-values between treatments within each trial (Table 5). The average decomposition rate in the pruning trial was found to be significantly higher than the average k-value in the accession trial.

(Insert figure 2)

(Insert table 5)

Significant $(P<0.05)$ correlations of $\mathrm{k}$ were found with the following initial leaf characteristics: \% C (-0.802), \% Mn (-0.778), \% Mg (0.758), \% P (0.701), C:P ratio (-0.679), $\mathrm{N}: \mathrm{P}$ ratio (-0.667), \% cellulose (0.617) and \% ash (-0.617).

\subsection{Nutrient release from decaying J. curcas litter}

The nutrient release patterns of $\mathrm{C}, \mathrm{N}, \mathrm{P}, \mathrm{K}, \mathrm{Mg}, \mathrm{Ca}, \mathrm{Na}$ and $\mathrm{Mn}$ are represented for each treatment in Figure 3. Differences between treatments were small, but could not be assessed using statistical methods since only one replication per treatment was analysed for nutrient content. The nutrient release pattern was found to vary considerably between the different nutrients. The release of $\mathrm{N}, \mathrm{P}, \mathrm{Mg}$ and $\mathrm{Na}$ was initially rapid in the first 2 weeks followed by a short immobilization phase for 2 to 3 weeks, after which the release gradually continued. Potassium release occurred at a high constant rate and was completed 8 weeks after incubation. In contrast, $\mathrm{Ca}$ and $\mathrm{Mn}$ were initially retained in the decaying leaf litter for 4 weeks before they were released at approximately the same rate as mass loss.

Nutrient release constants ( $\mathrm{k}$; see Table 6) were similar between treatments, with the exception of the $\mathrm{k}$ values of the pruning trial being higher for $\mathrm{C}, \mathrm{N}$ and $\mathrm{P} . \mathrm{K}, \mathrm{P}, \mathrm{Mg}$ and $\mathrm{Na}$ had nutrient release rates exceeding mass loss rate, thus were leached from the material. The rates of $\mathrm{C}$ and $\mathrm{N}$ release were similar to the mass loss rate, while $\mathrm{Mn}$ and $\mathrm{Ca}$ were retained in the litter during decomposition. The evolution of nutrient and fibre contents in the decaying litter is presented in Table 7. 
$\mathrm{N}$ and $\mathrm{P}$ release are known to be highly dependent on the chemical properties of litter (e.g. [36]), so correlations were calculated between their release constants and the initial litter nutrient content. Nitrogen release was significantly correlated with \% P (0.894), C:N ratio ($0.847), \% \mathrm{~N}(0.761), \mathrm{C}: \mathrm{P}$ ratio (-0.705), \% Mg (0.655), \% Mn (-0.652) and N:P ratio (-0.625). Likewise, phosphorus release was positively correlated with the initial phosphorus and nitrogen contents of the litter: \% $\mathrm{P}(0.871), \mathrm{C}: \mathrm{P}$ ratio $(-0.765), \mathrm{N}: \mathrm{P}$ ratio $(-0.735)$ and $\mathrm{C}: \mathrm{N}$ ratio $(-0.643)$.

(Insert figure 3)

(Insert table $6 \& 7$ )

\section{Discussion}

\subsection{Litter production}

Litterfall from the two-year old $J$. curcas trees in this study was low compared to other $J$. curcas studies conducted in other regions. Wani et al. [37] found an annual litter production of 0.92 and $2.42 \mathrm{Mg} \mathrm{ha}^{-1}$ for a 1- and 3-year old plantation $(2 \times 3 \mathrm{~m}$ plant spacing), respectively, in a region of India in a comparable agro-ecozone with similar rainfall characteristics. Our study resulted in an annual production of only $0.271 \mathrm{Mg} \mathrm{ha}^{-1}$ for the same $2 \times 3 \mathrm{~m}$ plant spacing. Also, compared with more humid regions, our average observed litter production (0.45 $\mathrm{Mg} \mathrm{ha}^{-1}$ ) is low. Firdaus \& Husni [38] reported $1.29 \mathrm{Mg} \mathrm{ha}^{-1} \mathrm{yr}^{-1}$ for a 1year old plantation $(2 \times 3 \mathrm{~m}$ spacing) in Malaysia at a site with an annual rainfall of 2200 mm, while Abugre et al. [7] reported 2.27 $\mathrm{Mg} \mathrm{ha}^{-1}, 1.10 \mathrm{Mg} \mathrm{ha}^{-1}$ and $0.79 \mathrm{Mg} \mathrm{ha}^{-1}$ for $1 \times 1$ $\mathrm{m}, 2 \times 1 \mathrm{~m}$ and $3 \times 1 \mathrm{~m}$ spacing, respectively, in Ghana with annual rainfall of $1300 \mathrm{~mm}$. In the current study, litter production was only measured during 3 months (May - July 2010), representing the peak leaf fall period, and therefore annual litterfall may be underestimated. The results obtained by Abugre et al. [7] and Firdaus \& Husni [38] suggest that in constantly humid regions $J$. curcas sheds its leaves continuously throughout the year, unlike in drier areas where leaf fall is seasonal. During the course of the experiment, part of the plantation suffered from infections caused by mealy bugs (Homoptera: Pseudococcidae), broad mites (Acari: Tarsonemidae) and powdery mildew (personal observation). In addition, in most of 
the pruned treatments, a high mortality of branches was observed after the first pruning in October 2009. These factors caused a decline in plant productivity, which in turn can partly explain the low litter production.

\subsection{Litter constituents}

Jatropha curcas litter is relatively poor in $\mathrm{N}$ and $\mathrm{P}$, but rich in $\mathrm{Ca}$ and $\mathrm{Mg}$ compared to other frequently used leguminous tree species in agroforestry projects in Africa (e.g., Leucaena leucocephala and Gliricidia sepium) [36,39]. In contrast litter of Ricinus communis (castor oil), from the same family as Jatropha, , contains more $\mathrm{N}(5.1 \%)$, less $\mathrm{P}(0.38 \%)$ and has a far lower C:N ratio (8.0) than J. curcas litter [40]. The average $\mathrm{N}$ content of J. curcas litter measured in this study is lower and the $\mathrm{C}: \mathrm{N}$ ratio is higher than those reported by Abugre et al. [7] for green J. curcas leaves from Ghana (i.e. 2.53\% and 16.7), whereas P and lignin concentrations are more similar between the two studies. These differences can be explained by nutrient resorption prior to abscission [24, 25]. The other reason could be the accumulation of specific nutrients mainly in the reproductive organs of the plant. High accumulation of $\mathrm{N}$ and $\mathrm{P}$ in the seed organ of $J$. curcas $\left(\mathrm{N}=49.5 \mathrm{~g} \mathrm{~kg}^{-1}, \mathrm{P}=4.4 \mathrm{~g} \mathrm{~kg}^{-1}\right)$ was observed by Wani et al. [37] compared to leaves $\left(\mathrm{N}=9.5 \mathrm{~g} \mathrm{~kg}^{-1}\right.$ and $\left.\mathrm{P}=0.7 \mathrm{~g} \mathrm{~kg}^{-1}\right)$ at plant age of 4 years. Leaf lignin contents found here are similar to those reported by Yamamura et al. [41] (9.1\%) and Ruíz-Valdiviezo et al. [23] (11.1\%).

Litter in our trial had very high K concentrations, exceeding all those presented by Drechsel and Zech [42] in a review of fresh leaves of tropical tree species and also higher than most studies presenting data on fresh or dry leaf litter of J. curcas. However, Camergo et al. [43] working in Brazil did report similarly high values of $\mathrm{K}$ in fresh leaves of J. curcas, exceeding their $\mathrm{N}$ concentrations, under unfertilized conditions. Here high amounts of $\mathrm{K}$ fertilizer had been applied and thus the foliar chemistry may reflect this. Potassium is highly mobile in plants [44]. In laboratory studies simulating severe drought conditions, it has been demonstrated that leaf $\mathrm{K}$ concentrations of $J$. curcas fresh leaves can increase to $2.44 \%$ (recalculated from Díaz-López et al. [45]). Given that in the current trial, the soil conditions were sandy, soil water retention is low and rainfall was low, these conditions might explain the high $\mathrm{K}$ concentrations found.

\subsection{Total nutrient input through J. curcas litterfall}


From the comparison between the nutrient input through J. curcas litterfall (Table 4) and a typical dose of mineral fertilizer applied in J. curcas plantations in Zambia, it becomes apparent that only 6.5, 0.9 and $9.1 \%$ of the estimated requirements for $\mathrm{N}, \mathrm{P}$ and $\mathrm{K}$ are covered by the litterfall nutrient flux (assuming a planting distance of $1.5 \times 2.5 \mathrm{~m}$ as was the case in this study). However, as the soil in this study area is characterised by deficiencies of N, P and $\mathrm{K}$ (Table 1), even this small contribution can be relevant for crop production. J. curcas yields a marketable product thus any soil fertility benefit is an additional benefit rather than the main reason for incorporating $J$. curcas in any intercropping system and highlight a significant advantage over typical hedgerow intercropping species. Indeed, Snapp et al. [46], working in southern Africa, and Nederlof and Dangbégnon [47] working in West Africa, concurred that technologies, such as integrating leguminous trees that only contribute to soil fertility are unlikely to be adopted by farmers unless they significantly lower labour requirements.

\subsection{Decomposition of J. curcas litter}

The average decomposition constant found in this study $\left(0.08\right.$ week $^{-1}$ or 0.035 day $\left.^{-1}\right)$ is much higher than the value of 0.018 day $^{-1}$ reported by Abugre et al. [7] for $J$. curcas leaf litter decomposition under similar conditions in Ghana, despite the lower $\mathrm{C}: \mathrm{N}$ ratio in the latter case (i.e. 17 versus 33). Low C:N ratio may not always be a reliable indicator of high decomposition rate. In Zambia for instance, litter of Senna siamea $(\mathrm{C}: \mathrm{N}=30, \mathrm{~N}=2.31$, lignin $=28 \%)$ was found to decompose as fast as L. leucocephala $(\mathrm{C}: \mathrm{N}=18, \mathrm{~N}=3.5$, lignin $=30 \%$ ) [50]. Jatropha curcas litter mass loss during decomposition was rapid, with a decrease of about $80 \%$ of the mass between 70 and 105 days, but is slow compared with $R$. communis in the same family (90\% within 35 days) [40]. This can be explained by the significantly higher $\mathrm{N}$ concentration (Muoghalu et al. [48]; Vanlauwe et al. [49]) of the latter.

No significant effects of accession, planting distance or pruning were found on the decomposition rate of $J$. curcas litter in this study. In case of the accession trial, this can be explained by the limited differences in litter quality observed between the accessions, which in turn, is known to be the most important determinant of litter decomposition within the same climate region [50,51]. Based on the results of Abugre et al. [7], who found a significantly higher decomposition rate of $J$. curcas litter under open canopy compared to closed canopy, an impact of canopy management on litter decay was expected in this study. 
This effect, however, appeared to be negligible. Instead, this study demonstrated that soil fertility might be an important factor to consider, as it can explain the higher rate of decomposition observed in the pruning trial compared to the other trials (Table 1).

\subsection{Nutrient release pattern from decaying J. curcas litter}

The main cations were released in the order $\mathrm{K}>\mathrm{Mg}>\mathrm{Ca}$, as was also observed by Palm \& Sanchez [35]. An initial immobilization of $\mathrm{Ca}$ and $\mathrm{Na}$ has been frequently observed in the tropics (e.g., [7,40,52]). An early immobilization of $\mathrm{Ca}$ has been attributed to an accumulation of calcium oxalate in decomposing fungi [53]. The accumulation of $\mathrm{Na}$ at the early stage of decomposition could be attributed to sodium input from rain or dust [48]. In

general $\mathrm{K}, \mathrm{P}, \mathrm{Mg}$ and $\mathrm{Na}$ showed a nutrient release constant which was larger than the mass decomposition constant. This can be explained by the high mobility and solubility of these nutrients, combined with high temperature and rain [54,55].

\section{Conclusion}

Jatropha curcas leaf litter decomposes rapidly but has a lower nutrient concentration than legume trees commonly grown in Africa. No effects of accession, spacing or pruning on litter decomposition of $J$. curcas were observed. The plant shows rapid release of nutrients. From an ecosystem service perspective, J. curcas has the potential to positively affect nutrient cycling and soil fertility in tropical intercropping systems, creating an extra added value besides biofuel production. However, as the total nutrient input through J. curcas litterfall to the soil is limited, organic or mineral fertilizers remain crucial to fully satisfy the nutrient requirements of surrounding crops.

\section{Acknowledgements}

This research was funded by KU Leuven University and supported by ERA-ARD Jatrophability project, ICRAF (Ethiopia) and the KLIMOS platform on sustainability transition financed by the Belgian Development Aid through VLIR/ARES. The first author highly acknowledges VLIR-UOS for funding his short research stay in Leuven during the preparation of this document. L. Norgrove is supported by the SNSF (Swiss National Science Foundation) through a Marie Heim-Vögtlin research fellowship in Agricultural and Forestry Sciences (grant PMPDP3_145502). Special thanks to Paul Mungwangwa, Matthew de Klerk, David Nganga and Kenneth Linyunga. 


\section{References}

[1] Achten WMJ, Verchot L, Franken Y, Mathijs E, Singh V, Aerts R, et al. Jatropha biodiesel production and use. Biomass Bioenergy 2008;32(12):1063-84.

[2] Openshaw K. A review of Jatropha curcas: an oil plant of unfulfilled promise. Biomass Bioenergy 2000;19(1):1-15.

[3] Ambrosi DG, Galla G, Purelli M, Barbi T, Fabbri A, Lucretti S, et al. DNA markers and FCSS analyses shed light on the genetic diversity and reproductive strategy of Jatropha curcas L. Diversity 2010;2(5):810-36.

[4] Misra M, Misra AN. Jatropha: The biodiesel plant biology, tissue culture and genetic transformation - A review. Int J Pure Appl Sci Technol 2010;1(1):11-24.

[5] Negussie A, Achten WMJ, Norgrove L, Hermy M, Muys B. Invasiveness risk of biofuel crops using Jatropha curcas L. as a model species. Biofuel bioprod biorefin 2013;7:48598. DOI: $10.1002 / \mathrm{bbb}$

[6] Negussie A, Achten WMJ, Verboven HAF, Hermy M, Muys B. Floral display and effects of natural and artificial pollination on fruiting and seed yield of the tropical biofuel crop Jatropha curcas L. GCB Bioenergy 2014;6:210-18. doi: 10.1111/gcbb.12072

[7] Abugre S, Oti-Boateng C. Litter fall and decomposition trend of Jatropha curcas L. leaves mulches under two environmental conditions. Agric Biol J North Am 2011;2(3):462-70.

[8] Negussie A. Regeneration ecology of Jatropha curcas L. in Africa: implications for its biofuel production and invasiveness. Doctoral thesis, Faculty of Bioscience Engineering, KU Leuven, Belgium. 2013. 166 pp. Available on https://lirias.kuleuven.be/handle/123456789/410001. 
[9] Muys, B., Norgrove, L., Alamirew, T., Birech, R., Chirinian, E., Delelegn, Y et al. Integrating mitigation and adaptation into development: the case of Jatropha curcas in sub-Saharan Africa. GC BBioenergy 2014;6:169-71.

[10] Grant PM. The fertilization of sandy soils in peasant agriculture. Zimbabwe Agric J $1981 ; 67: 131-37$.

[11] Morris M, Kelly V a, Kopicki RJ, Byerlee D. Fertilizer Use in African Agriculture:Lessons Learned and Good Practice Guidelines. vol. 44. Washington: The World Bank; 2007.

[12] Vanlauwe B, Coyne D, Gockowski J, Hauser S, Huising J, Masso C, et al. Sustainable intensification and the African smallholder farmer. Curr Opin Environ Sustain $2014 ; 8: 15-22$.

[13] Derra AN, Yélémou B, Sanon KB, Hilou A, Rasolodimby M, Hien V. Management patterns of Jatropha curcas : Impact on the microbial and the mycorrhizal biomasses in different phyto-geographic zones of Burkina Faso. Adv Appl Sci Res 2013;4(6):256-67.

[14] Dieng A, Ndoye I, Duponnois R, Baudoin E. Effects of Jatropha curcas L. plantation on soil bacterial and fungal communities. Soil Biol Biochem 2014 May;72:105-15.

[15] Karberg NJ, Scott NA, Giardina CP. Methods for Estimating Litter Decomposition. In: Hoover C., editor. For. Ecol. Manage., Springer Science + Business Media B.V.; 2008, p. $103-11$.

[16] Ranade S, Srivastava a, Rana T, Srivastava J, Tuli R. Easy assessment of diversity in Jatropha curcas L. plants using two single-primer amplification reaction (SPAR) methods. Biomass and Bioenergy 2008;32:533-40.

[17] Mugendi DN, Nair PKR, Mugwe JN, O’Neil MK, Swift MJ, Woomer PL. Alleycropping of maize with Calliandra and Leucaena in the subhumid highlands of 
Kenya: part 2: Biomass decomposition nitrogen mineralization and nitrogen uptake by maize. Agrofor Syst 1999;46:51- 64.

[18] Sileshi G, Mafongoya PL. Quantity and quality of organic inputs from coppicing leguminous trees influence abundance of soil macrofauna in maize crops in eastern Zambia. Biol Fertil Soils 2006;43:333-40.

[19] Henning RK. Jatropha curcas L. In: Plant Resources of the Tropical Africa (Volume 14). van der Vossen HAM, Mkamilo GS, editors. Vegetable oils PROTA Fondation.Wageningen, The Netherlands; 2007. p. 116-22.

[20] Jongschaap REE, Kenis M, Ellison C, Rouamba M, Freyer B. Jatropha growth and oilseed production in Africa. Jatropha Facts Series; Issue 1; ERA-ARD. Burn; Switherland:2013.

[21] Negussie A, Nacro S, Achten WMJ, Norgrove L, Kenis M, Hadgu KM, et al. Insufficient Evidence of Jatropha curcas L. Invasiveness: Experimental Observations in Burkina Faso, West Africa. BioEnergy Res 2014;8:570-80.

[22] García-Palacios P, Milla R, Delgado-Baquerizo M, Martín-Robles N, Álvaro-Sánchez M, Wall DH. Side-effects of plant domestication: Ecosystem impacts of changes in litter quality. New Phytol 2013;198:504-13.

[23] Ruíz-Valdiviezo VM, Luna-Guido M, Galzy A, Gutiérrez-Miceli FA, Dendooven L. Greenhouse gas emissions and $\mathrm{C}$ and $\mathrm{N}$ mineralization in soils of Chiapas (México) amended with leaves of Jatropha curcas L. Appl Soil Ecol 2010;46 (1):17-25.

[24] Aerts R. Nutrient resorption from senescing leaves of perennials: are there general patterns? J Ecol 1996; 84 (4):597-608.

[25] Hevia F, Minoletti ML, Decker KLM, Boerner REJ. Foliar nitrogen and phosphorus dynamics of three Chilean Nothofagus (Fagaceae) species in relation to leaf lifespan. Am J Bot 1999;86:447-55. 
[26] Rulli MC, Saviori A, D’Odorico P. Global land and water grabbing. Proc Natl Academy Sci 2013;110(3):892-97.

[27] Prescott CE. Do rates of litter decomposition tell us anything we really need to know? For Ecol Manag 2005;220:66-74.

[28] Chinene VRN. Detailed soil survey and Land evaluation of the University of Zambia farm. 1988. Soil Survey Report No. 160; Lusaka; Zambia.

[29] Kurz-Besson C, Coûteaux MM, Thiéry JM, Berg B, Remacle J. A comparison of litterbag and direct observation methods of Scots pine needle decomposition measurement. Soil Biol Biochem 2005;37 (12):2315-18.

[30] Harmon ME, Nadelhoffer KJ, Blair JM. Measuring decomposition, nutrient turnover, and stores in plant litter. In: Robertson GP, Coleman DC, Bledsoe CS, Sollins P, editors. Standard Soil Methods for Long-term Ecological Research, Oxford University Press, Oxford: 1999, p. 202-40.

[31] Van Soest PJ. Use of detergents in the analysis of fibrous feeds. II. A rapid method for the determination of fiber and lignin. J Association Off Ana Chem 1963;46(5):829..

[32] Van Soest PJ, Robertson JB, Lewis BA. Methods for dietary fiber, neutral detergent fiber and non-starch polysaccharides in relation to animal nutrition. Symposium on Carbohydrate methodology, metabolism and nutritional implications in dairy cattle. $\mathbf{J}$ Dairy Sci 1991;74(10):3563-97.

[33] Wieder RK, Lang GE. A critique of the analytical methods used in examining decomposition data obtained from litter bags. Ecology 1982;63:1636-42.

[34] Olson JS. Energy storage and the balance of producers and decomposers in ecological systems. Ecology 1963;44:322-31.

[35] Palm CA, Sanchez PA Decomposition and nutrient release patterns of the leaves of three tropical legumes. Biotropica 1990;22:330-38. 
[36] Tian G, Kang BT, Brussaard L. Effects of chemical composition on N, Ca and Mg release during incubation of leaves from selected agroforestry and fallow plant species. Biogeochem 1992;16:103-19.

[37] Wani SP, Chander G, Sahrawat KL, Rao CS, Raghvendra G, Susanna P, et al.Carbon sequestration and land rehabilitation through Jatropha curcas (L.) plantation in degraded lands. Agric Ecosys Environ 2012;161:112-20.

[38] Firdaus MS, Husni MHA. Planting Jatropha curcas on constrained land : Emission and effects from land use change. Sci J 2012;2012:1-7.

[39] Daldoum DMA, Mubarak AR, Elbashir AA. Leaf litter decomposition and nutrient release pattern of three tree species under semi-arid conditions. J Nat Resources Environ Studies 2010;5:75-88.

[40] Podgaiski LR, Rodrigues GG. Leaf-litter decomposition of pioneer plants and detritivore macrofaunal assemblages on coal ash disposals in southern Brazil. Eur J Soil Biol 2010; 46:394-400.

[41] Yamamura M, Akashi K, Yokota A, Hattori T, Suzuki S, Shibata D, et al.Characterization of Jatropha curcas lignins. Plant Biotechnol 2012;29(2):179-83.

[42] Drechsel P, Zech W. Foliar nutrient levels of broad-leaved tropical trees: a tabular review. Plant Soil 1991;131(1):29-46.

[43] Camargo de R, Maldonado AC, Dias PA, Souza MF, França MS. Diagnose foliar em mudas de pinhão-manso (Jatropha curcas L.) produzidas com biossólido. R Bras Eng Agríc Ambiental 2013;17(3):283-90.

[44] Rengel Z, Damon PM. Crops and genotypes differ in efficiency of potassium uptake and use. Physiologia Plantarum 2008;133(4):624-36.

[45] Díaz-López L, Gimeno V, Simón I, Martínez V, Rodríguez-Ortega WM, García-Sánchez F. Jatropha curcas seedlings show a water conservation strategy under drought 
conditions based on decreasing leaf growth and stomatal conductance. Agric Water Manag 2012;105:48-56.

[46] Snapp SS, Rohrbach DD, Simtowe F, Freeman HA. Sustainable soil management options for Malawi: can smallholder farmers grow more legumes? Agric Ecosyst Environ 2002;91:159-74.

[47] Nederlof ES, Dangbégnon C. Lessons for farmer-oriented research: Experiences from a West African soil fertility management project. Agr Hum Values 2007;24:369-387.

[48] Muoghalu JI, Adeleye OM, Balogun RT. Litter decomposition and inorganic element dynamics in a secondary rainforest at Ile-Ife, Nigeria. Afr J Ecol 1994;32:208-21.

[49] Vanlauwe B, Diels J, Sanginga N, Merckx R. Residue quality and decomposition: an unsteady relationship? In: Cadisch G, Giller GE, editors. Driven by nature: plant litter quality and decomposition. Wallingford, UK, CAB International: 1997. p. 157-66.

[50] Aerts R. Climate, leaf litter chemistry and leaf litter decomposition in terrestrial ecosystems: a triangular relationship. Oikos 1997;79 (3):439-49.

[51] Martínez-Yrízar A, Núñez S, Búrquez A. Leaf litter decomposition in a southern Sonoran Desert ecosystem, northwestern Mexico: Effects of habitat and litter quality. Acta Oecologica 2007;32(3):291-300.

[52] Swift MJ, Russell-Smith A, Perfect TJ. Decomposition and mineral-nutrient dynamics of plant litter in a regenerating bush-fallow in sub-humid tropical Africa. J Ecol 1981;69: 981-95.

[53] Cromack KJR, Todd RL, Monk CD. Patterns of basidiomycete nutrient accumulation in conifer and deciduous forest litter. Soil Biol. Biochem 1975;7:265-68.

[54] Oladoye AO, Adedire MO, Agboola DA. Nutrient dynamics and litter decomposition in Leucaena leucocephala (Lam.) De Wit plantation in the Nigerian derived savannah. West Afr J Appl Ecol 2003;13:96-103. 
[55] Norgrove L, Hauser S, Weise SF. Response of Chromolaena odorata to timber tree densities in an agrisilvicultural system in Cameroon: aboveground biomass, residue decomposition and nutrient release. Agric Ecosyst Environ 2000;81:191-207. 


\begin{tabular}{|c|c|c|c|c|c|c|}
\hline \multirow[b]{3}{*}{ Properties } & \multicolumn{6}{|c|}{ Experimental trials and soil sampling depth $(\mathrm{cm})$} \\
\hline & \multicolumn{2}{|c|}{ Accession trial } & \multicolumn{2}{|c|}{ Plant spacing trial } & \multicolumn{2}{|c|}{ Pruning trial } \\
\hline & $0-30$ & $30-90$ & $0-30$ & $30-90$ & $0-30$ & $30-90$ \\
\hline Available $\mathrm{P}\left(\mathrm{mg} \mathrm{kg}^{-1}\right)$ & 1.86 & 1.51 & 2.14 & 0.81 & 3.33 & 1.02 \\
\hline $\mathrm{K}\left(\mathrm{mmol} \mathrm{kg}{ }^{-1}\right)$ & 6.30 & 5.60 & 7.70 & 8.30 & 5.90 & 5.60 \\
\hline $\mathrm{Ca}\left(\mathrm{mmol} \mathrm{kg}^{-1}\right)$ & 13.85 & 11.10 & 23.75 & 21.50 & 15.45 & 13.30 \\
\hline $\operatorname{Mg}\left(\mathrm{mmol} \mathrm{kg}^{-1}\right)$ & 3.15 & 4.65 & 8.70 & 12.85 & 2.85 & 3.25 \\
\hline $\mathrm{Na}\left(\mathrm{mmol} \mathrm{kg}{ }^{-1}\right)$ & 2.20 & 2.10 & 2.30 & 2.50 & 2.20 & 2.10 \\
\hline $\mathrm{Cu}\left(\mathrm{mg} \mathrm{kg}^{-1}\right)$ & 0.24 & 0.20 & 0.52 & 0.46 & 0.24 & 0.24 \\
\hline $\operatorname{Mn}\left(\mathrm{mg} \mathrm{kg}^{-1}\right)$ & 16.96 & 11.22 & 29.64 & 10.48 & 10.26 & 15.38 \\
\hline $\mathrm{Fe}\left(\mathrm{mg} \mathrm{kg}^{-1}\right)$ & 7.18 & 4.36 & 9.10 & 3.16 & 5.08 & 5.58 \\
\hline $\mathrm{AL}^{3+}\left(\mathrm{mmol} \mathrm{kg}^{-1}\right)$ & 0.07 & 0.13 & 0.10 & 0.17 & 0.10 & 0.03 \\
\hline $\mathrm{H}^{+}\left(\mathrm{mmol} \mathrm{kg}{ }^{-1}\right)$ & 0.40 & 1.60 & 0.80 & 0.70 & 1.10 & 0.90 \\
\hline $\mathrm{S}\left(\mathrm{mg} \mathrm{kg}^{-1}\right)$ & 0.67 & 1.17 & 1.50 & 0.33 & 1.00 & Trace \\
\hline $\mathrm{Zn}\left(\mathrm{mg} \mathrm{kg}^{-1}\right)$ & 0.58 & 0.22 & 0.90 & 0.24 & 0.66 & 0.30 \\
\hline $\mathrm{B}\left(\mathrm{mg} \mathrm{kg}^{-1}\right)$ & Trace & Trace & 0.09 & Trace & 0.11 & 0.01 \\
\hline $\mathrm{EC}\left(\mathrm{mscm}^{-1}\right)$ & 0.23 & 0.13 & 0.22 & 0.14 & 0.18 & 0.17 \\
\hline $\mathrm{pH}\left(\mathrm{CaCl}_{2}\right)$ & 5.34 & 5.32 & 5.65 & 5.62 & 5.92 & 6.44 \\
\hline Soil Organic matter $\left(\mathrm{g} \mathrm{kg}^{-1}\right)$ & 15.20 & 6.40 & 20.80 & 8.00 & 12.00 & 5.60 \\
\hline Soil Organic Carbon $\left(\mathrm{g} \mathrm{kg}^{-1}\right)$ & 8.80 & 3.70 & 12.10 & 4.60 & 7.00 & 3.20 \\
\hline Sand $(\%)$ & 82.8 & 76.8 & 76.8 & 64.8 & 84.8 & 78.8 \\
\hline Clay (\%) & 10.0 & 18.0 & 16.0 & 32.0 & 8.0 & 18.0 \\
\hline Silt (\%) & 7.2 & 5.2 & 7.2 & 3.2 & 7.2 & 3.2 \\
\hline Texture class & LS & SL & SL & SCL & LS & SL \\
\hline
\end{tabular}

Note: LS (Loam Sand), SL (Sandy Loam), SCL (Sandy Clay Loam)

${ }^{1}$ Table 1 Chemical and physical properties of the top $90 \mathrm{~cm}$ of soil at the experimental sites, Chongwe, Zambia (source: QUINVITA NV 2011, unpublished, extraction methods not specified). 
Table $2^{2}$

\begin{tabular}{lc}
\hline Trial and treatment & $\begin{array}{c}\text { Leaf litter production } \\
\left(\mathbf{k g ~ h a}^{-1}\right)\end{array}$ \\
\hline Accession $\left(\mathbf{2 6 6 7} \mathbf{~ h a}^{-1}\right)$ & 581 \\
Cape Verdean & 419 \\
Indian & 573 \\
Malian & 557 \\
Mexican & 517 \\
Thai & 568 \\
Zambian & \\
\hline Plant density (Cape Verdean accession) & 418 \\
2500 ha $^{-1}$ & 271 \\
1667 ha & -1 \\
625 ha $^{-1}$ & 111 \\
\hline Pruning (Cape Verdean accession, 1667 ha & -1 \\
Non-Pruned & 418 \\
Pruned $^{-1}$ & 517 \\
\hline
\end{tabular}

2 Table 2 Dry matter litter production of different $J$. curcas accessions and canopy management practices (plant age $=2$ years) during May - July 2010 in Chongwe, Zambia. 
Table $3^{3}$

\begin{tabular}{|c|c|c|c|c|c|c|c|c|c|c|c|c|c|}
\hline \multirow[b]{2}{*}{$\begin{array}{l}\text { Trial and } \\
\text { treatment }\end{array}$} & \multicolumn{13}{|c|}{ Leaf litter constituents } \\
\hline & $\begin{array}{l}\mathrm{C} \\
\left.\mathrm{g} \mathrm{kg}^{-1}\right)\end{array}$ & $\begin{array}{l}\mathbf{N} \\
\left(\mathrm{g} \mathrm{kg}^{-1}\right)\end{array}$ & $\begin{array}{l}\mathrm{C}: \mathrm{N} \\
\text { ratio }\end{array}$ & $\begin{array}{l}\mathbf{P} \\
\left(\mathrm{g} \mathrm{kg}^{-1}\right)\end{array}$ & $\begin{array}{l}\mathbf{K} \\
\left(\mathrm{g} \mathrm{kg}^{-1}\right)\end{array}$ & $\begin{array}{l}\text { Ca } \\
\left(\mathrm{g} \mathrm{kg}^{-1}\right)\end{array}$ & $\begin{array}{l}\mathrm{Mg} \\
\left(\mathrm{g} \mathrm{kg}^{-1}\right)\end{array}$ & $\begin{array}{l}\mathrm{Na} \\
\left(\mathrm{g} \mathrm{kg}^{-1}\right)\end{array}$ & $\begin{array}{l}\text { Mn } \\
\left(\mathrm{g} \mathrm{kg}^{-1}\right)\end{array}$ & $\begin{array}{l}\text { Hemi- } \\
\text { cellulose } \\
\left(\mathrm{g} \mathrm{kg}^{-1}\right)\end{array}$ & $\begin{array}{l}\text { Cellulose } \\
\left(\mathrm{mg} \mathrm{kg}^{-1}\right)\end{array}$ & $\begin{array}{l}\text { Lignin } \\
\left(\mathrm{g} \mathrm{kg}^{-1}\right)\end{array}$ & $\begin{array}{l}\text { Ash } \\
\left(\mathrm{g} \mathrm{kg}^{-1}\right)\end{array}$ \\
\hline \multicolumn{14}{|l|}{ Accession } \\
\hline Cape Verdean & 430.8 & 12.08 & 35.7 & 0.82 & 18.75 & 28.30 & 8.53 & 0.59 & 1.00 & 48.0 & 53.8 & 207.3 & 6.0 \\
\hline Indian & 425.2 & 11.82 & 36.0 & 0.79 & 20.24 & 21.05 & 6.66 & 0.60 & 1.12 & 44.1 & 44.7 & 237.9 & 6.0 \\
\hline Malian & 412.7 & 12.38 & 33.3 & 0.89 & 18.15 & 24.94 & 5.69 & 0.50 & 1.43 & 54.0 & 77.8 & 140.3 & 5.9 \\
\hline Mexican & 429.3 & 12.25 & 35.1 & 1.27 & 18.93 & 24.37 & 4.74 & 0.38 & 1.43 & 48.6 & 39.8 & 138.9 & 6.0 \\
\hline Thai & 405.1 & 11.78 & 34.4 & 0.88 & 21.05 & 33.39 & 8.43 & 0.62 & 1.16 & 59.2 & 89.4 & 125.3 & 6.0 \\
\hline Zambian & 397.6 & 12.57 & 31.6 & 0.96 & 24.58 & 31.49 & 9.83 & 0.79 & 1.48 & 58.4 & 111.0 & 104.8 & 6.0 \\
\hline \multicolumn{14}{|l|}{ Plant spacing } \\
\hline $2500 \mathrm{ha}^{-1}$ & 392.6 & 13.42 & 29.3 & 1.55 & 29.52 & 28.45 & 9.79 & 0.49 & 1.02 & 80.0 & 138.0 & 80.2 & 5.9 \\
\hline $1667 \mathrm{ha}^{-1}$ & 369.6 & 9.98 & 37.0 & 1.37 & 36.90 & 37.87 & 10.53 & 0.41 & 0.63 & 59.8 & 162.4 & 70.9 & 6.0 \\
\hline $625 \mathrm{ha}^{-1}$ & 378.2 & 9.72 & 38.9 & 1.06 & 41.19 & 30.93 & 8.76 & 0.43 & 0.86 & 71.0 & 168.4 & 73.7 & 5.9 \\
\hline \multicolumn{14}{|l|}{ Pruning } \\
\hline Non-pruned & 384.1 & 14.16 & 27.1 & 1.94 & 30.43 & 37.61 & 10.26 & 0.44 & 0.65 & 68.1 & 127.3 & 75.0 & 5.9 \\
\hline Pruned & 373.5 & 15.32 & 24.4 & 1.41 & 27.88 & 25.17 & 11.81 & 0.31 & 0.45 & 54.0 & 119.4 & 82.0 & 5.9 \\
\hline
\end{tabular}

\footnotetext{
${ }^{3}$ Table 3 Dry leaf litter chemical constituents of different $J$. curcas accessions and canopy managements after 2 years in Chongwe, Zambia.
} 
Table $4^{4}$

\begin{tabular}{|c|c|c|c|c|c|c|c|c|}
\hline \multirow[b]{2}{*}{$\begin{array}{l}\text { Trial and } \\
\text { treatment }\end{array}$} & \multicolumn{8}{|c|}{ Nutrients } \\
\hline & $\begin{array}{c}\mathrm{C} \\
\left(\mathrm{kg} \mathrm{ha}^{-1}\right)\end{array}$ & $\begin{array}{c}\mathrm{N} \\
\left(\mathrm{kg} \mathrm{ha}^{-1}\right)\end{array}$ & $\begin{array}{c}P \\
\left(\mathrm{~kg} \mathrm{ha}^{-1}\right)\end{array}$ & $\begin{array}{c}\mathrm{K} \\
\left(\mathrm{kg} \mathrm{ha}^{-1}\right)\end{array}$ & $\begin{array}{c}\text { Ca } \\
\left(\mathrm{kg} \mathrm{ha}^{-1}\right)\end{array}$ & $\begin{array}{c}\text { Mg } \\
\left(\mathrm{kg} \mathrm{ha}^{-1}\right)\end{array}$ & $\begin{array}{c}\mathrm{Na} \\
\left(\mathrm{kg} \mathrm{ha}^{-1}\right)\end{array}$ & $\underset{\left(\mathrm{kg} \mathrm{ha}^{-1}\right)}{\mathrm{Mn}}$ \\
\hline \multicolumn{9}{|l|}{ Accession } \\
\hline Cape Verdean & 250.5 & 7.02 & 0.48 & 10.90 & 16.45 & 4.96 & 0.34 & 0.58 \\
\hline Indian & 178.0 & 4.95 & 0.33 & 8.47 & 8.81 & 2.79 & 0.25 & 0.47 \\
\hline Malian & 236.6 & 7.10 & 0.51 & 10.41 & 14.30 & 3.26 & 0.29 & 0.82 \\
\hline Mexican & 239.3 & 6.83 & 0.71 & 10.55 & 13.58 & 2.64 & 0.21 & 0.80 \\
\hline Thai & 209.6 & 6.10 & 0.46 & 10.89 & 17.28 & 4.36 & 0.32 & 0.60 \\
\hline Zambian & 225.9 & 7.14 & 0.55 & 13.96 & 17.89 & 5.58 & 0.45 & 0.84 \\
\hline \multicolumn{9}{|l|}{ Plant spacing } \\
\hline $2500 \mathrm{ha}^{-1}$ & 163.9 & 5.60 & 0.65 & 12.32 & 11.88 & 4.09 & 0.20 & 0.43 \\
\hline $1667 \mathrm{ha}^{-1}$ & 161.8 & 2.71 & 0.60 & 16.16 & 16.58 & 4.61 & 0.18 & 0.28 \\
\hline $625 \mathrm{ha}^{-1}$ & 42.1 & 1.08 & 0.12 & 4.59 & 3.44 & 0.98 & 0.05 & 0.10 \\
\hline \multicolumn{9}{|l|}{ Pruning } \\
\hline Non-pruned & 160.5 & 5.92 & 0.81 & 12.71 & 15.71 & 4.29 & 0.18 & 0.27 \\
\hline Pruned & 193.0 & 7.92 & 0.73 & 14.40 & 13.00 & 6.10 & 0.16 & 0.23 \\
\hline
\end{tabular}

\footnotetext{
${ }^{4}$ Table 4 Total annual leaf nutrient release to the soil from different $J$. curcas accessions and under different canopy management.
} 
Table $5^{5}$

\begin{tabular}{lccc}
\hline $\begin{array}{l}\text { Trial and } \\
\text { treatment }\end{array}$ & $\mathbf{k}$ & $\mathbf{k}-\mathbf{C I}$ & $\mathbf{k}+\mathbf{C I}$ \\
\hline Accession & & & \\
Cape Verdean & 0.069 & 0.055 & 0.083 \\
Indian & 0.082 & 0.066 & 0.098 \\
Malian & 0.072 & 0.060 & 0.084 \\
Mexican & 0.068 & 0.050 & 0.086 \\
Thai & 0.085 & 0.069 & 0.101 \\
Zambian & 0.081 & 0.063 & 0.099 \\
\hline Average & 0.076 & 0.069 & 0.081 \\
\hline Plant spacing & & & \\
2500 ha & & & \\
1667 ha $^{-1}$ & 0.079 & 0.061 & 0.097 \\
625 ha $^{-1}$ & 0.087 & 0.069 & 0.105 \\
\hline Average & 0.088 & 0.068 & 0.108 \\
\hline Pruning & 0.085 & 0.075 & 0.095 \\
\hline Non-pruned & & & \\
Pruned & 0.098 & 0.076 & 0.120 \\
\hline Average & 0.101 & 0.081 & 0.121 \\
\hline
\end{tabular}

5 Table 5 The decomposition rate constant $\left(\mathrm{k}\right.$; in weeks $\left.{ }^{-1}\right)$, together with its confidence intervals $(\mathrm{CI})$, obtained by fitting a single exponential function on the mass decomposition data for each treatment. 


\begin{tabular}{|c|c|c|c|c|c|c|c|c|}
\hline $\begin{array}{l}\text { Trial and } \\
\text { treatment }\end{array}$ & C & $\mathbf{N}$ & $\mathbf{P}$ & $\mathbf{K}$ & Mg & $\mathbf{C a}$ & $\mathrm{Na}$ & Mn \\
\hline \multicolumn{9}{|l|}{ Accession } \\
\hline Cape Verdean & 081 & 0.069 & 0.126 & .252 & .127 & 0.061 & 0.125 & 0.054 \\
\hline Indian & 0092 & 0083 & .152 & 0.248 & 141 & & .179 & 0.078 \\
\hline Malian & 0.080 & 0.072 & 0.121 & 0.223 & .119 & 55 & 0.099 & 056 \\
\hline Mexican & 0.076 & 0.075 & 0.192 & 0.228 & .121 & 0.062 & 0.129 & 0.079 \\
\hline Thai & & 0.083 & & & & & & 0.072 \\
\hline Zan & 0.083 & 0.081 & .175 & 0.313 & 1 & 085 & .201 & 0.090 \\
\hline Average & 0005 & 0077 & & & & 8 & & 0.072 \\
\hline \multicolumn{9}{|l|}{ Plant spacing } \\
\hline $2500 \mathrm{~h}$ & 083 & 0.090 & 0.203 & 0.223 & 0.127 & 0.078 & 0.125 & 0.079 \\
\hline $1667 \mathrm{ha}^{-1}$ & 090 & 0.071 & 0.178 & 0.284 & 0.115 & 0.073 & 0.113 & 0.085 \\
\hline $625 \mathrm{~h}$ & 0.093 & 0.079 & 0.148 & 0.317 & 0.101 & 0.063 & 0.106 & 0.071 \\
\hline Average & 0.088 & 0.079 & 0.174 & 0.268 & 0.115 & 0.071 & 0.115 & 0.079 \\
\hline \multicolumn{9}{|l|}{ Pruning } \\
\hline &  & & & 2 & 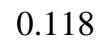 & 00 & 0.11 & 0.086 \\
\hline Prun & 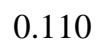 & 0 & 272 & 6 & .168 & 0.055 & 0.079 & 0.066 \\
\hline Average & 0.106 & 0.118 & 0.197 & 0.193 & 0.140 & 0.059 & 0.090 & 0.073 \\
\hline
\end{tabular}

${ }^{6}$ Table 6 The nutrient release constant $\left(\mathrm{k}\right.$, in weeks $\left.{ }^{-1}\right)$ for each treatment and nutrient obtained by fitting a single exponential function to the nutrient release data. 
$4 \quad$ Table $7^{7}$

\begin{tabular}{|c|c|c|c|c|c|c|c|c|c|c|c|c|c|c|c|}
\hline $\begin{array}{c}\text { Time } \\
\text { (week) }\end{array}$ & $\underset{\left(\mathrm{g} \mathrm{kg}^{-1}\right)}{\mathrm{C}}$ & $\underset{\left(\mathrm{g} \mathrm{kg}^{-1}\right)}{\mathbf{N}}$ & $\begin{array}{c}\mathbf{C}: \mathbf{N} \\
(-)\end{array}$ & $\underset{\left(\mathrm{g} \mathrm{kg}^{-1}\right)}{\mathbf{P}}$ & $\underset{\left(\mathrm{g} \mathrm{kg}^{-1}\right)}{\mathrm{K}}$ & $\underset{\left(\mathrm{g} \mathrm{kg}^{-1}\right)}{\mathrm{Mg}}$ & $\underset{\left(\mathrm{g} \mathrm{kg}^{-1}\right)}{\mathrm{Ca}}$ & $\underset{\left(\mathrm{g} \mathrm{kg}^{-1}\right)}{\mathrm{Na}}$ & $\underset{\left(\mathrm{g} \mathrm{kg}^{-1}\right)}{\operatorname{Mn}}$ & $\begin{array}{c}\mathbf{C}: \mathbf{P} \\
(-)\end{array}$ & $\begin{array}{c}\mathbf{N}: \mathbf{P} \\
(-)\end{array}$ & $\begin{array}{c}\text { Cellulose } \\
\left(\mathrm{g} \mathrm{kg}^{-1}\right)\end{array}$ & $\begin{array}{c}\text { Hemi- } \\
\text { cellulose } \\
\left(\mathrm{g} \mathrm{kg}^{-1}\right)\end{array}$ & $\underset{\left(\mathrm{g} \mathrm{kg}^{-1}\right)}{\text { Lignin }}$ & $\underset{(-)}{\text { Lignin: }}$ \\
\hline 0 & 399.9 & 12.3 & 33.0 & 1.4 & 26.1 & 8.6 & 29.4 & 0.5 & 1.0 & 357.7 & 10.6 & 102.9 & 58.7 & 121.5 & 100.2 \\
\hline 2 & 394.3 & 10.1 & 39.5 & 0.8 & 19.0 & 7.3 & 32.6 & 0.4 & 1.0 & 571.8 & 14.1 & 148.7 & 81.1 & 108.5 & 109 \\
\hline 4 & 386.3 & 11.2 & 34.7 & 0.8 & 11.7 & 7.2 & 36.9 & 0.4 & 1.1 & 616.4 & 17.4 & 172 & 54.7 & 144.8 & 130.2 \\
\hline 8 & 371.8 & 13.5 & 27.7 & 0.7 & 1.7 & 4.6 & 35.4 & 0.3 & 1.1 & 575.4 & 20.7 & 103.2 & 27.5 & 210.4 & 158.1 \\
\hline 14 & 331.9 & 13.1 & 25.9 & 0.8 & 1.8 & 3.4 & 30.5 & 0.3 & 1.0 & 448.2 & 17.7 & 97 & 46 & 265.6 & 207.1 \\
\hline 24 & 350.3 & 14.8 & 24.0 & 1.0 & 2.0 & 3.3 & 26.8 & 0.4 & 1.1 & 384.3 & 16.5 & 70.6 & 56.5 & 198.7 & 118.5 \\
\hline 34 & 374.7 & 12.7 & 30.3 & 1.1 & 2.8 & 3.3 & 26.3 & 0.5 & 0.9 & 379.6 & 13.0 & - & - & - & - \\
\hline
\end{tabular}

5

6

${ }^{7}$ Table 7 Nutrient concentrations in remaining $J$. curcas litter at each time step, averaged for all treatments. C:N, C:P. N:P are mass ratios and are therefore unitless. 